\title{
Western Balkan Integration to EU
}

\author{
Msc. Shkelzen Imeri' \\ Diplomat, Ministry of Foreign Affairs, bioalma_79@yahoo.com
}

Dr. Marsela Sako ${ }^{2}$

Faculty of Social Science, Department of Political Science, University of Tirana; marsela sako@yahoo.com

\section{Doi:10.5901/mjss.2016.v7n3s1p164}

\section{Abstract}

Performance of candidate countries to EU is assessed as weak and with problems in the function of state institutions, which are considered as the main challenges for the security of Western Balkan and its EU integration. The other problem is the insufficient economic development that has great influence in the Western Balkan security. Countries in the region are faced even with the consequences of this problem like high unemployment, poverty and social tensions. Western Balkan leaders need to take serious initiatives on economic reform, with the goal to increase economic indicators and moreover living standards. EU countries have the necessity to understand the importance of Western Balkan countries for peace and security, simultaneously the need for economic and political assistance for reaching standards. The aim of this article is to give modest ideas for the acceleration of Western Balkan integration process in EU.

Keywords: integration, reforms, security, competition, assistance, corruption, law enforcement, economic cooperation, and performance.

\section{Introduction}

Historical developments in the Balkans are characterized by ethnic rivalries and bloody conflicts, consequences of political conflicts.

On the historical perspective, Balkans has been the main road of Romans to the East and of ottomans to the West. During different occupations each invader has left a nation or a religion, where each hated one another to the death. ${ }^{1}$ ${ }^{1}$ During these historical conflicts, the fundamental problem exist in the contradiction among geopolitics and ethnic borders, lack of appropriate political mechanisms and of the will to solve these contradictions. In most of the cases solution has been brought forth through use of force, which has planted the seed of new conflicts and accompanied with violence in the Balkan and beyond.

USA and EU engagement helped the Balkan to get out of war in peace, from the stable development of disintegration, where through NATO a Euro-Atlantic future was brought forth. Without the powerful engagement of the Euro-Atlantic Alliance the fundamental changes that have happened in the Balkans could have never been achieved nor have stable development. These are reflected in the internal regional and border agreements and beyond.

\section{The Balkans and the Issues toward EU.}

Balkans EU integration is not only a desire of the countries that make it. On the other hand it will depend on the will of $\mathrm{EU}$, which in most of the cases is contradictory. EU countries reduce their national sovereignty with the aim to strengthen their international influence, an influence unreachable if acted unilaterally. On this perspective, reduction of national sovereignty towards EU, meaning in practice member states delegates some of decision-making powers to existing joint institutions.

Despite that national sovereignty is still an insuperable barrier in the development of a common and proper foreign policy, without mentioning common defence policy and the establishment of a joint army. ${ }^{2} 2$

Balkan countries EU integration is somehow a question of standards and values adopted in the national and

\footnotetext{
1 George Friedman, Future 100 Years, Plejad 2010, pg 66.
}

2 Desmond Dinan, European Union Policies, AllS, pg 272. 
regional reality, before being a question of technical negotiations and of political dialogue or of European and global conjectures. Integration process neither is nor depended mainly from the progress of local, national and regional factors in the Balkan countries.

If we had developed countries and integrated regions according to EU doctrine, even the enlargement would not have reasons to slow down. Albania and the region in its entirety have many challenges to reach integration values and standards. The process would always be depended from internal EU developments, especially from the acceptance policy of new members with full rights. The birth of different kinds of problems in EU and world conflicts (economic global crisis, refugee crisis, terrorism, etc.) has stimulated EU sceptics to slow down the enlargement process.

\section{Western Balkan Countries Challenges Towards EU}

Western Balkan presently is threatened and endangered from: weak institutions, corruption, poverty, organised crime and terrorism. $^{3}$

It faces another fundamental and important problem that deals with the establishment and function of state institutions. In a quick view, establishment of institutions through nepotism, otherwise called as phenomena of state dissolution, is a phenomenon that threatens security and is a real challenge for all countries in the region. American NGO "Fund for Peace" in one of its reports, assesses the stability of EU candidate countries from institutional point of view, "in pre-warning" areas. This study includes 177 countries and is based on 12 indicators: 6 political, 2 economical and 4 social, which determine: government ability (or governmental institutions) to exercise control in the country's territory, offering public services, level of corruption and criminality, level of population involuntary movement and economic recession. 4

Weakness and functional state institution problems are considered the main challenges for Western Balkan security and its EU integration. The above-mentioned arguments are based on the fact that in modern political regimes, the state has an obligation to establish and guarantee structures that regulate economic and political activity of the society. Beside this, legal structures and established institutions by the state including their function in accordance to international standards, assure its presence in the international economical and political system. As a consequence, structures can not function on satisfactory levels, subsystems of society that are connected to economy, justice and policy will not function in their internal activity, including the foreign one. This issue has a particular importance, in cases when states are not able or have great difficulties to modernise without international assistance, as are Western Balkan states. Pre-Accession Instrument in EU, is focused on strengthening institutions, because only a country with strong institutions may fulfil Copenhagen Criteria. ${ }^{5}$

Main criticism for the moment is toward the practical function of institutions and their structural gap.

EU Independent experts identified real measures that aim at raising institutions independence, transparency, professionalism, function and public trust like: Ombudsman, Commissioner for Anti-Discrimination, Asset Declaration Inspectorate, etc. it was agreed on the strengthen of legal framework and institutional through a number of horizontal measures for all independent institutions. ${ }^{6}$

When discussing on institutions, take in consideration civil service institutions, political, military, police and law institutions. During transition period, the most dynamical reform in the region has been in military sector. Yugoslav People's Army (Jugoslavenska narodna armija - JNA) in the 1990's has had 180.000 active soldiers, 1850 tanks, 455 planes and 198 military helicopters. Albania in the 1980's had an active army made up of 61.000 military forces, 260.000 in reserve and a considerable number of volunteer forces. In the end of the 1990's armed forces reached a number of 100.000 people. $^{7}$

In an analysis of a Serbian journal "Blic", Serbian Army is made up of 33 thousand military forces, 80 planes and 272 tanks. Macedonia has about 8 thousand military forces and 3 tanks. Bosnia and Herzegovina has 11 thousand military forces, 19 planes and 188 tanks. Croatia NATO's member has 16 thousand military forces, 32 planes and 86 tanks. Slovenia, NATO's member has 7100 military forces, 24 planes and 54 tanks. Montenegro has 2100 military forces and 4 planes. Kosovo has 2500 military forces and 800 in reserve. ${ }^{8}$

\footnotetext{
${ }^{3}$ www.zeriamerikes.com Organized crime obstacle for integration 27022010.

${ }^{4}$ www.global.fundforpeace.org/index.php June 2010.

${ }^{5}$ http.//www.eeas.europa.eu/delegacions European Council Copenhagen 1993.

${ }^{6}$ delegation-albaniaqeeas.europa.eu. Seminar Tirane 2015.

${ }^{7}$ https.//lajmi i fundit.wordpss.com/2012/07, shkurtime ne ushtri. Zv/mimistri i Mbrotjes, Arian Starova.

${ }^{8}$ www.zeri.info/.../ serbia ushtrin me te forte ne Ballkane 07/05/2013 gazeta Blic.
} 
According to Defence Minister Ms Kodheli, the Albanian Army will lay off in 20151500 troops from the actual 10.000. The Army budget is $0,85 \%$ of GDP. It is forecasted that the Army budget in 2015 to go to $2 \%$ level of GDP. For 2016 it is forecasted military purchase of 17 million \$ armament and in 2025 it is forecasted this value to go to 38 million $\$ 9^{9}$

Referred to the International Institute for Peace in Stockholm Report, Albania's military spending go up to 3,131 billion \$ during 1992-2013 period. Macedonia has spend 3 billions and 46 million \$ during 1996-2013 period. In 2001 Macedonia was unstable and spent 436 million \$. Bosnia and Herzegovina has spend 3 billions and 90 million \$ during 2002-2013. Montenegro has spend 626 million and 800 thousand \$ during 2006 - 2013. 10

Actually, the greatest challenges are political reform as these reforms are the basis for the Europeanization of the region's countries. This process requires dynamic and pragmatic actions, not based on ideology or Balkan provincial leadership. Naturally, it is thought for the process to be lead by leaders whom, for the security of their country. To judge on strategic viewpoint and regionally, to have political vision to consider Euro-Atlantic integration process of their countries as a political process, this requires its own maturation period.

Not far from importance is economic development. Momentarily is not on right proper rhythms and is not enough to exercise greater influence in the Western Balkan.

Each of the countries in the region is faced with consequences of such condition like high unemployment, poverty, exodus and social tension. Polarization of social conflicts in some cases is done on ethnic bases. James Clapper, USA Intelligence community director, in a report to Senate Committee stated, "Conditions in Bosnia and Herzegovina and Macedonia is unstable due to ethnic division. Macedonian government continues to support programs that aim to encourage Macedonian nationalism against Euro-Atlantic integration of the country". ${ }^{1111}$ to security.

Fragility of state institutions and insufficient economic development influence directly on the issues that are related

Unemployment in Western Balkan in last two decades varies from 20-25\%. Majority of graduates cannot find job due to corruption and nepotism. In most of the cases, they go to the higher instances, by creating obstacles to opportunities that are created for stable economic development. In none of the regions' countries like Albania, Kosovo, Macedonia, Bosnia and Montenegro, no young can have a career if not engaged in some political parties. In a detailed analysis of DW, related to refugee crisis, one of the problems for Balkan countries is also the issue of Roma community, which deal with sharp economic and social problems. Often they are discriminated not for their ethnical background but suffer from their collapse of social security. ${ }^{12}$

Moreover, Western Balkan countries, according to World Bank report of 2015, ranks among 10 countries with low income per capita and more precisely Kosovo with 3390 \$, Albania 4450 \$, Bosnia 4760 \$, Macedonia 5150 \$, Montenegro 7320 \$, Bulgaria 7620 \$, Rumania 9520 \$. ${ }^{13}$

In a quick view incomes in the region are fluctuated in a medium level of $5300 \$$, and compared to incomes of EU countries, are comprised of $31 \%$ of their medium. If measured with the performance of European political initiatives, the region is ranked at the bottom according to "Catch Up" index, which measures 35 countries in Europe, takes in consideration economic indicators, life quality, democracy and governance. Bosnia and Herzegovina and Albania are ranked at the bottom of this study, while Kosovo is not even considered.

According to these data, Balkan countries unfortunately are indicators of the fact that the time of economic growth and approximation with developed countries has finished. IMF forecast on the region's performance is gloomy. Economic growth is forecasted to be among 2-3.5\%, excluding Montenegro which foresees an economic growth of $4 \%{ }^{14}$

The study of Valbona Zeneli PhD, expert at "George Marshall" centre, related to the forecast of economic growth in Balkan countries, states that if in these countries would exit an economic growth of $7 \%$ per year, and then they would need 25-36 years to double their revenues and 50 years to reach the European average. Another argument in her study is related to the threat in the region, which is a result of unemployment that reaches over $24 \%$ and is double that of EU. 15

One of the biggest failures during transition period is economic informality and great social inequality. Negative

\footnotetext{
${ }^{9}$ www.telegrafi.com/.../sa Instituti Ndërkombëtar i Kërkimeve për Paqen në Stokholm. 28/06/2014, çdo vit publikon shifrat e shpenzuara nga 171 shteteteve.

${ }^{10}$ www-gazeta-shqiptare.com. Shkurtime ne ushtri, 14.12.2015.

11 www.zeriamerikes.com Rraportim ne Senatin Amerikane, James Clapper, Drejtor i zb. 29 janar 2014.

12 html//www.dw.com/sq/fokus Deshtimi i Elitave politike ne Ballkan date 17 gusht 2015.

13 http/www. EXLPRESS. Pse ngec Ballkani, 18/02/2016.

14 http.worldbank.org/sq. Raporti BB per ardhura per fryme 2015.

15 albania-arkiva.blogspot.com/2015/06/varferia-rreziku-kryesor. dr. Valbona Zeneli, Drejtoresh e studimeve ne qendren George C. Marshall.
} 
economic indicators are the poor performance in creating competitive markets and improvement of entrepreneurship, as poor and low indicators of production. Average level of GDP per capita in Balkan countries is nearly $40 \%$ of average in EU countries. Calculated on the principle of buying power is as followed: Rumania 31\%, Greece 29\%, Bulgaria 11\%, Serbia 9\%, Croatia 8\%, while Kosovo, Montenegro, Macedonia, Albania, Bosnia share among them 12\% of region's GDP. ${ }^{16}$

Countries region are assessed with weak competitive force in relation to global competition at the World Economic Forum. Factors that contribute in this dishonest competition is the unfriendly environment towards business. Rule of law and law enforcement leaves a lot to be desired, while innovation in economy is negligible.

Corruption is deeply rooted and includes political and institutional elites. Croatia has the greatest achievement in the fight against corruption, including arrest and punishment of high political figures (ex Prime Minister Sanader). In Albania is arrested and attending trial ex minister of Labour and Social Welfare, Spiro Ksera.

In general, Western Balkan countries are described as autocratic where corruption and close relation to political elite and organised crime dominates the political landscape. The slow transition to the path of democracy and rule of law in the Balkan has caused discontent in EU, which has turned its attention to other hotbeds like Greece and Ukraine. Consequence of such condition is the migration waves, mainly young people. The exodus of young graduated people makes for their engagement in social changes in their country to be inexistent. This has given rise to desperation that can bring a certain "dictatorship" from which every young and intellectual wish to escape as soon as possible. ${ }^{17}$

Poverty and inequality is another challenge for security in the Balkan, which includes illegal immigration toward EU countries. In a World Bank report, the number of immigrants in 1990 was $13 \%$ and in 2013 reached 25\%. Nearly 4.9 million Albanians have left the Balkan area. Up until August 2015, in Germany, there were 38, 245 asylum seekers from Albania, 33.824 from Kosovo, 20.864 Serbs and 10.244 Macedonians.

This marked a record in request for economic asylum. ${ }^{18}$ Regional uncertainty situations have created a negative image for the region in the eyes of foreign investors. The phenomenon is seen in the reluctance to invest in the Balkans due to the unstable political and economical situation. An indicator for this fact is the attraction of less than $0,9 \%$ of foreign global investment from the whole region. ${ }^{19}$

Countries of the region are faced with economical crime (money laundering), drug traffic, weapons, human trafficking, smuggling, violent crimes, nationalism, etc. Money laundering from 2004-2013, in Serbia, went up to 30.83 billion $\$$, Croatia at $40^{\text {th }}$ place with 34.5 billion $\$$, Bulgaria at $47^{\text {th }}$ with 25 billion $\$$, Macedonia 5 billion $\$$, Montenegro at $108^{\text {th }}, 2.5$ billion $\$ .20$ According to Global Financial Integrity (GFI) money coming from crime, corruption and fiscal evasion have cost to the Balkans a staggering 111,6 billion \$ during 2001-2010.

Organised crime in the region is able to infiltrate the political sphere more than other countries of Europe, due to weak institutions. Transparency International has published Corruption Perception Index for 2015, where Kosovo is ranked $103^{\text {rd }}$, Albania $88^{\text {th }}$, Serbia $71^{\text {st }}$, Macedonia $66^{\text {th }}$, Montenegro $61^{\text {st }} .{ }^{21}$

As consequence of this phenomenon institutional reforms are stumbled. As conclusion, it has to be said that weak institutions, corruption and organised crime, are the main obstacles of Western Balkans Europeanization.

\section{Conclusions}

Western Balkan leaders need to take serious initiatives in reforming the economy with the intention to have growth in economic indicators and improvement of living standards. Due to the crisis, growth cannot be immediate. On this viewpoint, every country in the region, in accordance to specific problems, need to secure necessary financial sources for their accomplishment.

It is judged for reforms to be structural, including also the improvement of business climate. Investments need to be implemented overall on human capital, keeping in consideration the requirements of the labour market and not going after just a graduation at universities.

Western Balkan countries need to increase the level of regional economic integration, as apart they comprise small market and cannot attract huge and serious investors. In this direction, region's countries make possible for this initiative

\footnotetext{
${ }^{16} \mathrm{http} / \mathrm{www} . X L P R E S S$. Pse ngec Ballkani, 18. 02. 2016

${ }^{17}$ www.dw.com/sq/koment-deshtimi i elitave ne ballkan17.08.2015

${ }^{18}$ www. BIRN.al Emigrantet nga Ballkani Gjergj Erebara 29092015.

19 http.worldbank.org/sq varferia rezik kryesor i ballkanit 11062015.

${ }^{20}$ www.gazeta-shqip.com, pastrimi i parave ne Ballkan, citon raportin e Global Financial Integrity. 31 korrik 2013.

${ }^{21}$ www.gazetaexpress.com/lajmet/ti, referohet Organizates TI Indeksi Preceptimi i Korrupsionit per 2015. 24 shkurt 2016.
} 
not to remain alone on the political aspect but to be implemented in practice.

Security challenges are the growth of regional commerce, cooperation and accomplishment of joint investments. This will give impetus to the local economies of each country. On the other hand, EU countries need to understand that lack of stability in the Balkans may cause instability to them, including massive flux of economic refugees and asylum seekers. It is to be judged that EU needs to assess the contribution of Western Balkan countries for peace and stability. In this framework it is always welcome from these countries for the offering of assistance in political and economical aspects and achieving standards.

Attempts for Euro-Atlantic integration, strengthening security and political and economical progress are in the hand of political elites and of the people themselves in the Western Balkans.

\section{References}

George Friedman, 100 Vitet e Ardhshme, Plejad 2010, fq 66.

Desmond Dinan, Politikat e Bashkimit Europian, AllS, fq 272.

www.zeriamerikes.com Krimi i organizuar pengese per integrim 27/02/2010.

www.global.fundforpeace.org/index.php Qershor 2010.

http.//www.eeas.europa.eu/delegacions Keshilli Evropian Kopenhagen 1993.

delegation-albaniaqeeas.europa.eu. Seminar Tirane 2015.

https.//lajmi i fundit.wordpss.com/2012/07, shkurtime ne ushtri. Zv/mimistri i Mbrotjes, Arian Starova.

www.zeri.info/.../ serbia ushtrin me te forte ne Ballkane 07/05/2013 gazeta Blic.

www.telegrafi.com/.../sa Instituti Ndërkombëtar i Kërkimeve për Paqen në Stokholm. 28/06/2014, çdo vit publikon shifrat e shpenzuara nga 171 shteteteve.

www-gazeta-shqiptare.com. Shkurtime ne ushtri, 14.12.2015.

www.zeriamerikes.com Rraportim ne Senatin Amerikan, James Clapper, Drejtor i zb. 29 janar 2014.

html//www.dw.com/sg/fokus Deshtimi i Elitave politike ne Ballkan date 17 gusht 2015.

http/www.EXLPRESS. Pse ngec Ballkani, 18/02/2016.

http.worldbank.org/sq. Raporti BB per ardhura per fryme 2015.

albania-arkiva.blogspot.com/2015/06/varferia-rreziku-kryesor. dr. Valbona Zeneli, Drejtoresh e studimeve ne qendren George C. Marshall.

http/www.XLPRESS. Pse ngec Ballkani, 18. 02. 2016

www.dw.com/sq/koment-deshtimi i elitave ne ballkan17.08.2015

www. BIRN.al Emigrantet nga Ballkani Gjergj Erebara 29092015.

http.worldbank.org/sq varferia rezik kryesor i ballkanit 11062015.

www.gazeta-shqip.com, pastrimi i parave ne Ballkan, citon raportin e Global Financial Integrity. 31 korrik 2013.

www.gazetaexpress.com/lajmet/ti, referohet Organizates TI Indeksi Preceptimi i Korrupsionit per 2015. 24 shkurt 2016. 